\title{
SCIENCE EDUCATION IN SCHOOLS AND AT TERTIARY LEVEL: STATUS QUO OR EMBRACING CHANGE?
}

André du Plessis

Nelson Mandela University, South Africa

Society is changing as the influence of technologies and the implementation of innovative practices are driving change. Change and innovation are not simple processes for all (Rogers, 2003). Yet, companies, corporates and small business are managed and lead to ensure not only efficiency, but also to yield the best possible financial gain. When one analises change in the world of commerce, one does not have to be a rocket scientist to come to the conclusion that there have been tremendous changes. Not only has the ergonomics of buildings and factories changed, there has also been change pertaining to the number of people employed, as technologies afford opportunities to make certain positions that people occupied, redundant. Robotic tools are used more and more in the manufacturing chain to increase productivity and to ensure greater quality, or so we are informed.

At the same time, schools and tertiary institutions have not been able to escape innovation and change. In some instances, great progress has been made, however, progress according to whom? Whose lens or lenses are utilised to make these claims? The claim pertaining to greater access and more learners and students entering the system and completing qualifications does, in my opinion, not necessarily suggest enhanced learning, greater consciousness regarding the challenges in society, greater learning skills, an increased opportunity to be employed or to create one's own employment, etc.

The above begs the following questions:

- To what extent have the schooling and tertiary system embraced change related to science teaching and learning?

- How just is the schooling and tertiary system?

- Do these two systems promote education that has as its core the promotion of social justice and greater equity? Or are these systems actually perpetuating the status quo?

I am aware that readers might by now have come to the conclusion that I am generalising and that this is not the case in his/her context or country. Well, the reader could be correct, but that does not imply that one should not ask these questions, because after critical self-reflection, many readers might come to this conclusion too.

Prensky (2009) advocated several $21^{\text {st }}$ century skills in his 2009 writing titled Marc Prensky's Essential $21^{\text {s Century }}$ Skills. He posited that "[k]nowing the right thing to do, [g]etting it done, [d]oing it with others, [d]oing it creatively" and "[c]Constantly doing it better" (Prensky, 2009, IS'), are not enough, but that "[t]he [w]orld [n]eeds a [n]ew [c]urriculum" (Prensky, 2014, IS), i.e. a curriculum that focuses on as he stated, "changing WHAT we teach" (Prensky, 2014, IS). I am quite certain the Prensky is not the only person who advocates for change, as there are change proponents in virtually every country, if not all countries. You are probably asking, so what is the point that I am trying to make? Well, it is quite rudimentary, as I am arguing that structures in real-life have changed significantly over the last twenty years, i.e. how we do things, what we do and why we do it. Those in leadership and influential positions have

1 IS refers to Internet Source, no page number 
made arguments for why they had to make changes and adapt. However, if we interrogate the school and tertiary system, how much change has occurred within these systems? Moreover, to what extent have these systems not only improved science learning, but also made changes to how science is taught and experienced by learners and students? Have they? Should we perhaps not be worried about Elliot's (2009) comment that the teacher of 1900 would probably feel as comfortable in the school classroom as the teacher of 2009 ? Could this also be said about the science classroom? Hence, is the education system adapting and changing to promote better science learning, greater access and social justice or has change to how science is taught and experienced (and perhaps many other subjects or disciplines) not been addressed at the level that it could have been? One aspect that seems to be prevalent in many school classrooms and lecture halls, is that ICT resources are utilised. However, it appears that in many instances these devices have merely replaced the chalkboard, whiteboard or posters. New tools have been implemented, but these tools are utilised in the same manner than the traditional tools. As such, it seems that pedagogy has not really changed. In addition, it appears that in society, the perception of a real scientist seems to be that of male, white and elderly, wearing glasses and a person wearing a white laboratory coat. Are these perceptions above still valid or are they rather the exception than the norm? Have we been able to change these perceptions related to pedagogy and to being a scientist can be someone of any gender and any ethnicity? These are tough questions that require deep thinking.

I do believe that change is possible. As such, what I am advocating is that we have to think how Science Education can be made interesting, exciting and enticing to all, and not only to those who we categorise as being clever or gifted. This could then lead to systemic change that we as educators and lecturers drive. In order to achieve this, I propose that the science community and governments rethink not only how we teach science, why we teach science and what we teach in science, but also engage with the same questions pertaining to most, if not all, school and tertiary subjects or disciplines. It was inspiring to note that many of the above aspects referred to are indeed receiving attention in projects aiming to make Science Education and Science in particular more accessible and attractive, for example projects, research and heuristics to promote for example scientific literacy (Barber, Pearson, Cervetti, Hiebert \& Bravo, 2012; Du Plessis, 2013; Osborne, 2010; Pearson, Moje \& Greenleaf, 2010; Their, 2010; Villanueva \& Hand, 2011; Villanueva \&Webb, 2008; Webb, 2009, 2010; Webb \& Mayaba, 2010; Webb \& Treagust, 2006). The above is merely a tip of the iceberg of some initiatives, with several authors promoting social justice in Science Education (Barton \& Upadhay, 2010; Dawson, 2017; Greenberg, 2017; Maulucci \& Fann, 2016; Zembylas, 2005), to name a few. However, more has to be done to bring about social change in Science Education.

It is thus suggested that those who can and want to be involved in the 'Changing of Science Curriculum, Classroom, School and Tertiary' movement have to engage in discussions and research that have the potential to influence not only policy related to how schools of the future should look structurally, but also which systemic changes should be made to promote social justice at governmental level. Furthermore, movements advocating change should also educationally influence WHAT is included in the curriculum, WHY it should be included and strategies that could be implemented HOW to facilitate the envisioned Science learning. We owe this to our children and the future generations and hence it is time to become more actively involved in promoting social justice not only in Science, but also within the greater society. If the above necessitates that the current way that school systems and tertiary systems are structured have to be critically analysed and changed to bring about greater good to the benefit of all humanity, then this is a worthy project. We cannot afford that the teacher or lecturer of 1900 feels as comfortable in 2018 in his/her classroom context than the teacher or lecturer of 2018, because this would probably imply that not a great deal of change has occurred in the system.

The above leaves you and me with another important question: Are we those agents who promote change and social justice within the Science community? Can we assist to transform and reform not only Science Education, but also Education in its totality? We might think that we do not have the power to do so, but then the pen is mightier than the sword and even small gains are gains. As such, it is suggested that the Journal of Baltic Science Education should invite through a special themed issue at least once a year authors to submit research related to the promotion of social justice and/or systemic change in Science Education. This might also require the utilisation of different research methodologies, for example participatory visual methodologies (Mitchell, De Lange \& Moletsane, 2017) as the methodology that we embark upon might assist us in influencing policy decision making. Science Education and education in general should not be about efficiency and investing the least amount of resources, rather, school and tertiary Science Education and education in general should be reconceptualised to afford each individual to gain from the system and not to be marginalised due to the context in which the individual is hosted. Our education should and must promote social justice. 
Let us revisit the questions that I have posed in the bulleted points. What are your answers to these questions? Is the status quo virtually still intact, have there been marginal change(s) or significant change(s) within your science teaching and learning context? Each one of us might have different answers to these questions above. What is your response to these questions?

\section{References}

Barber, J., Pearson, P. D., Cervetti, G, Hiebert, E. H., \& Bravo, M. (2012). Seeds of science/roots of reading: Program overview, program components and features. The Regents of the University of California. Retrieved 22 September 2013 from http://www.scienceandliteracy.org/sites/scienceandliteracy.org/files/pdf/SEEDS_Program_Overview_Sections_A_and_B.pdf.

Barton, A. C., Upadhyay, B. (2010). Teaching and learning science for social justice: Introduction to the Special Issue, 43 (1), 1-5.

Dawson, E. (2017). Social justice and out-of-school science learning: Exploring equity in science television, science clubs and maker spaces. Science Education, 101 (4), 539-547. http://doi.org/10.1002/sce.21288.

Mitchell, C., De Lange, N., \& Moletsane, R. (2017). Participatory visual methodologies: Social change, community and policy. New York: SAGE.

Elliot, B. (2009). E-Pedagogy: Does e-learning require a new approach to teaching and learning? Retrieved on June 15, 2009 from http://www.scribd.com/doc/932164/E-Pedagogy.

Greenberg, D. (2017). Why science teachers should care about social justice. I wonder ... Rediscovering School Science, 03, (70-73). Available on http://www.punyamishra.com/wp-content/uploads/2017/03/ScienceEd-SocialJustice-iWonder3.pdf.

Maulucci M. S. R., Fann K. T. (2016). Teaching for social justice in science education. In L. Avraamidou (Eds), Studying science teacher identity. New directions in mathematics and science education (pp. 111-128). Rotterdam: Sense Publishers.

Osborne, J. (2010). Arguing to learn in science: The role of collaborative, critical discourse. Science, 328, 463-466.

Pearson, P. D., Moje, E. B., \& Greenleaf, C. (2010). Literacy and science: Each in the service of the other. Science, 328, 459-463.

Prensky, M. (2009). Marc Prensky `s essential 21 st century skills. Available on https://doane21 st.wikispaces.com/file/view/PrenskyEssential_21stCenturySkills.pdf.

Prensky, M. (2014). The world needs a new curriculum. Available on http://marcprensky.com/wp-content/uploads/2013/05/ Prensky-5-The-World_Needs_a_New_Curriculum.pdf.

Rogers, E. M. (2003). Diffusion of innovations. $5^{\text {th }}$ Edition. New York: Free Press.

Thier, M. (2010). Science and literacy: Tools for life. Science Scope, 33 (6), 32-35.

Villanueva, M. G., \& Hand, B. (2011). Science for all: Engaging students with special needs in and about science. Learning Disabilities Research \& Practice, 26 (4), 233-240.

Villanueva, M. G., \&Webb, P. (2008). Scientific investigations: The effect of the'Science Notebooks' approach in Grade 6 classrooms in Port Elizabeth, South Africa. African Journal of Research in Mathematics, Science and Technology Education, 12 (2), 5-18.

Webb, P. (2009). Towards an integrated learning strategies approach to promoting scientific literacy in the South African context. International Journal of Environmental and Science Education, 4 (3), 313-334.

Webb, P. (2010). Science education and literacy: Imperatives for the developed and developing world. Science, 328 (5977), 448 - 450.

Webb, P., \& Mayaba, N. (2010). The effect of an integrated strategies approach to promoting scientific literacy on grade 6 and 7 learner's general literacy skills. African Journal of Research in Mathematics, Science and Technology Education, 14 (3), 35-50.

Webb, P., \& Treagust, D. F. (2006). Using exploratory talk to enhance problem-solving and reasoning skills in grade-7 science classrooms. Research in Science Education, 36 (4), 381-401.

Yore, L. D., Pimm, D., \& Tuan, H. L. (Eds.). (2007). Language - An end and a means to mathematical literacy and scientific literacy [Special issue]. International Journal of Science and Mathematics Education, 5 (4), 557-769.

Zembylas, M. (2005). Science education: For citizenship and/or for social justice? Journal of Curriculum Studies, 36 (6), $709-722$. 